\title{
Pseudomonas chlororaphis subspecies aureofaciens
}

National Cancer Institute

\section{Source}

National Cancer Institute. Pseudomonas chlororaphis subspecies aureofaciens. NCI

Thesaurus. Code C86698.

A species of aerobic, Gram negative, rod shaped bacteria in the phylum Proteobacteria.

This species is motile, non spore forming, displays a yellow color in certain growth media, can use both 5 ketogluconate and arabinose as a carbon source and produces phenazine 1 carboxylate. P. aureofaciens is not known to be a human pathogen. A strain of this species is used as a microbial pesticide for controlling various fung al diseases of golf course turf. 